\title{
四分木構造格子を導入した自然河川における 分岐点と合流点の数値解法 \\ 2D COMPUTATION OF CONFLUENCE AND BIFURCATION \\ IN NATURAL RIVERS WITH HIERARCHICAL QUADTREE GRID SYSTEM
}

\author{
星野 剛 ${ }^{1} \cdot$ 安田 浩保 ${ }^{2} \cdot$ 永多 朋紀 $^{3}$ \\ Tsuyoshi HOSHINO, Hiroyasu YASUDA and Tomonori NAGATA \\ 1 学生員 新潟大学大学院 自然科学研究科 ( $\bar{\top} 950-2181$ 新潟市西区五十嵐 2 の町 8050 ) \\ 2 正会員 工博 新潟大学准教授災害・復興科学研究所 (广950-2181 新潟市西区五十嵐 2 の町 8050) \\ 3 正会員 寒地土木研究所寒地河川チーム ( $062-7602$ 札幌市豊平区平岸 1 条)
}

\begin{abstract}
Numerical computation of river flows have been employed the general coordinate system to adjust a river plane form. An adjustment flexibility of the coordinate system is better but it is difficult to generate a grid system in order to compute stably because grid system is not determined uniquely. This study develops a new boundary fitting method introducing the hierarchical quad-tree grid system for computation of confluence and bifurcation in natural rivers. The numerical model with the quad-tree grid system apply to compute flow pattern in experiment flume and in natural river with bifurcation and confluence, the computed results agree with measured result of the flume and natural river well.
\end{abstract}

Key Words: quad-tree grid system, bifurcation, confluence, shibetsu river, shallow water equation

\section{1. はじめに}

開水路の合流部や分岐部の問題は古くから研究され

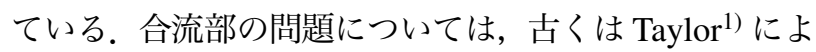
る 1 次元の運動量保存則を導入したものや板倉ら ${ }^{2)} に$ よる実験值に基づき支川の流速分布を求めたものなど がある. 分流部の問題についての研究は合流部の研究 と比べて一段と少ない. 一次元の問題として考えれば 分かる通り, 陽的に流量配分を決定することができな いことがこの問題の困難さの根本的な要因だろう。さ らに，自然河川の分岐部では，流量配分比に加えて，流 砂量配分比を流量配分比とは独立に決定しなければな らない。これに対し, 芦田ら ${ }^{3)}$ は実験的に取り組み，フ ルード数と分岐角度の観点から流量配分比の特性につ いて調べている. 長谷川 ${ }^{4)}$ は運動量保存則を巧みに適 用して堰を有する分岐部における流量配分比を求める ことに成功している．守屋・長谷川ら 5) は移動床分岐 部ついての理論解を求め, 不安定条件を明らかにした。 理論的な観点からは以上のように基本的性質の一端が 解明されたに過ぎないというのが現状である.

合流部や分岐部の流況と河床変動を同時に扱う様々 な数值計算が行われるようになってきている. 平面 2 次 元解析 ${ }^{6)}$ から発展して, 最近では合流部の複雑な水理 の適切な解析のために水深方向にも計算格子を設定し た準三次元ないしは三次元計算も行わ机るようになっ てきている7).しかし, 同問題の既往のほとんどの研 究では本川と支川を直角に合流させた単純な形状を対
象にすることに留まり，本格的に自然河川の分岐や合 流部を取扱った研究は少ない. 最近になり, Mung ら ${ }^{8)}$ は一般座標を重合格子のように繋ぎ合せることで自然 河川の合流部の解析が可能であることを示した。

このように現状では自然河川の分岐や合流部の解析 にすぐさま適用できる知見は少ない，その理由として， 前述した水理学的な煩雑さに加え, 分合流部や境界部 の境界適合が容易に行えないことが大きな要因として 挙げられる，分合流部を含む自然河川を一般座標によ り境界適合した場合 ${ }^{9)}$, 大きく歪曲した格子を含まざ るを得えず, この時, 格子構成の自由度と引き換えに計 算の安定性が犠牲にされる。この問題は格子構成に対 して要請される数学的条件を満足することで解消され るものの, 自然河川の格子構成においてこの条件を満 たすためには極めて煩雑な試行錯詋が必要となる。そ のうえ, 歪曲が大きな格子を有する格子構成では同じ 格子構成のままで定常流量から洪水流量までを一貫し て安定に解析できる保証はない.

これに対し, 四分木構造格子を利用した格子構成 ${ }^{10)}$ では, 格子構成に対する数学的な制約条件は存在しな い上，計算精度に密接に関係する格子の直交性もまた 完璧に保証される。しかも，このような利点を有しな がら, 一般座標の格子構成で要求される試行錯誤が不 要のために格子構成の大部分を自動処理できる大きな アドバンテージもある，本論文では，室内実験と自然 河川の分岐部や蛇行部に対して四分木構造格子による 格子構成を適用し, その妥当性について検討を加える. 
表-1 実験条件

\begin{tabular}{|c|c|c|c|c|}
\hline 河床勾配 & 合流後流量 $(1 / \mathrm{s})$ & \multicolumn{2}{|c|}{$\begin{array}{c}\text { 流量比 } \\
\text { (本川: }\end{array}$} & \multicolumn{2}{|c|}{ 川幅(m) } \\
\hline $1 / 200$ & 3.5 & $3: 1$ & 0.4 & 0.2 \\
\hline
\end{tabular}

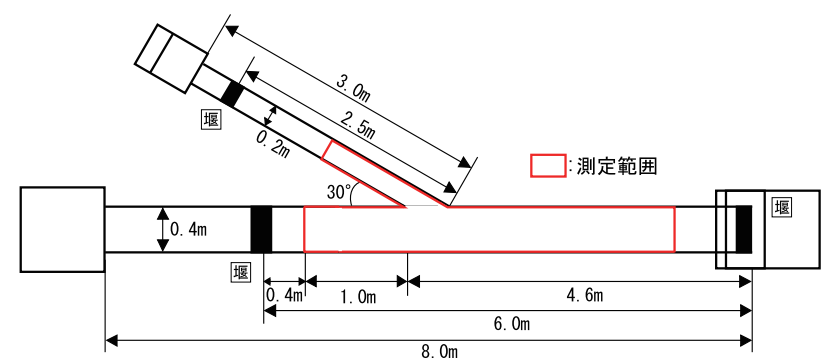

図-1 水路形状 ${ }^{11)}$

\section{2. 水路実験の再現計算}

\section{(1) 実験概要}

四分木構造格子による河川の合流部の流況の再現性 を確認するために水路実験の再現計算を行った。再現 計算の対象としたのは重枝らによる水路実験 ${ }^{11)}$ である. この実験は河川の合流部での流況の把握を目的として, 2 本の直線水路を $30^{\circ}$ で合流させ，水位を測定してい る。この実験水路の形状を図-1に示す。実験条件は固 定床での実験である CaseA-2 を用い, その際の水理条 件を表-1に示す.

\section{(2) 計算格子}

再現計算に用いた計算格子を図-2 に示す。格子サイ ズは $1,2,4 \mathrm{~cm} の 3$ 種類とし, 水路の平面形状の形状を 適切に反映させるために壁際で最小格子となるように 設定した。ここで用いた計算格子は著者らによって考

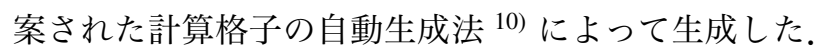
入力情報として水路の平面形状を与えるだけで自動的 に格子が生成できることがこの生成法の優位性のひと つである。

\section{(3) 支配方程式}

支配方程式にはこれまでの著者らの研究 10) と同様の 浅水流方程式を用いた。

\section{（4）計算条件・境界条件}

河床せん断力の決定には Manning-Strickler による平 坦河床の抵抗則 ${ }^{12)}$ を使用し, 河床材料の粒径には実験で 用いられた粒径 $0.00075 \mathrm{~m}$ を用いた。このとき Manning の粗度係数は 0.0141 と算出され，この粗度係数を計算 に使用した。

計算の上流端の境界条件には流量フラックスを本川, 支川それぞれに実験での流量と等しくなるように横断

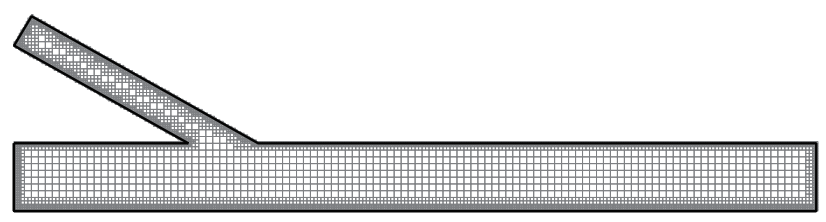

図-2 計算格子

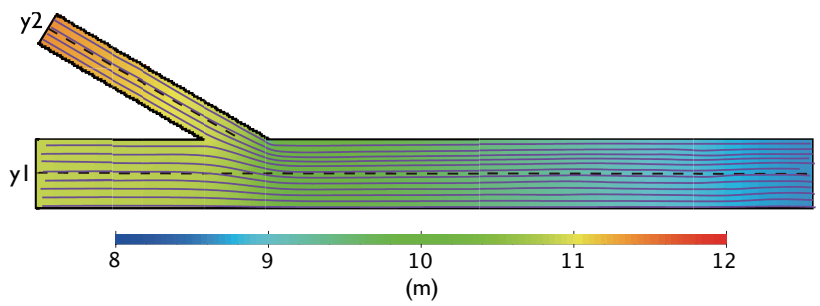

図-3 計算結果（水位コンター図，流線）

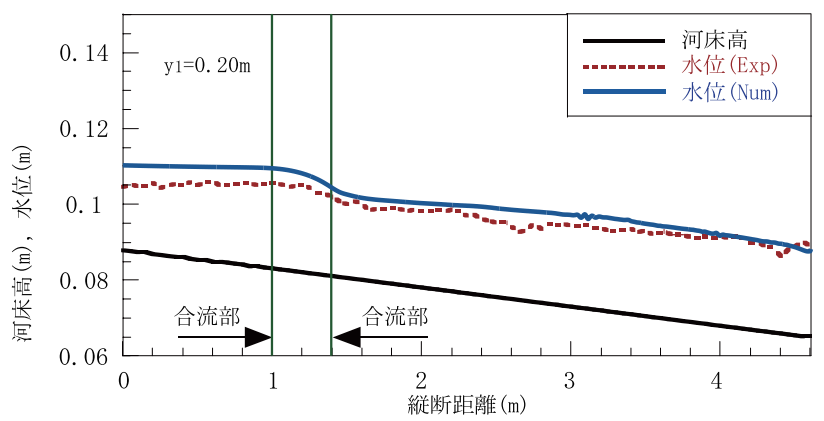

a) 本川

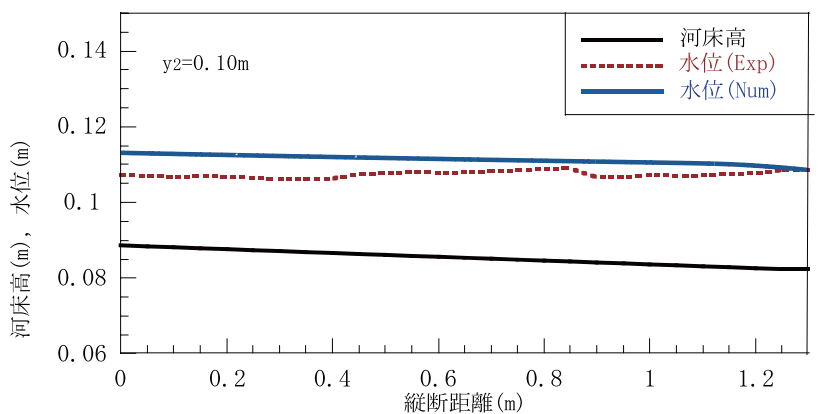

b) 支川

図-4 実測值と計算值（水位）

方向に一様に与えた。下流端の境界条件には実験で観 測された水位を横断方向に一様に与えた。この条件で 定常状態に達するまで計算を行った。

\section{(5) 計算結果}

計算結果の平面的な水位分布および流線を図-3に示 す. 図-3 から水面と流線の連続性が確認でき, デカル 卜座標を基準とした格子構成においても合流部の計算 が可能であると判断できる。特に支川との合流部のよ うに流向の異なる流れが合流する箇所でさえも一体的 に計算されていることがわかる。また，合流部下流側 での横断方向の水深は本川左岸側で小さく右岸側で大 


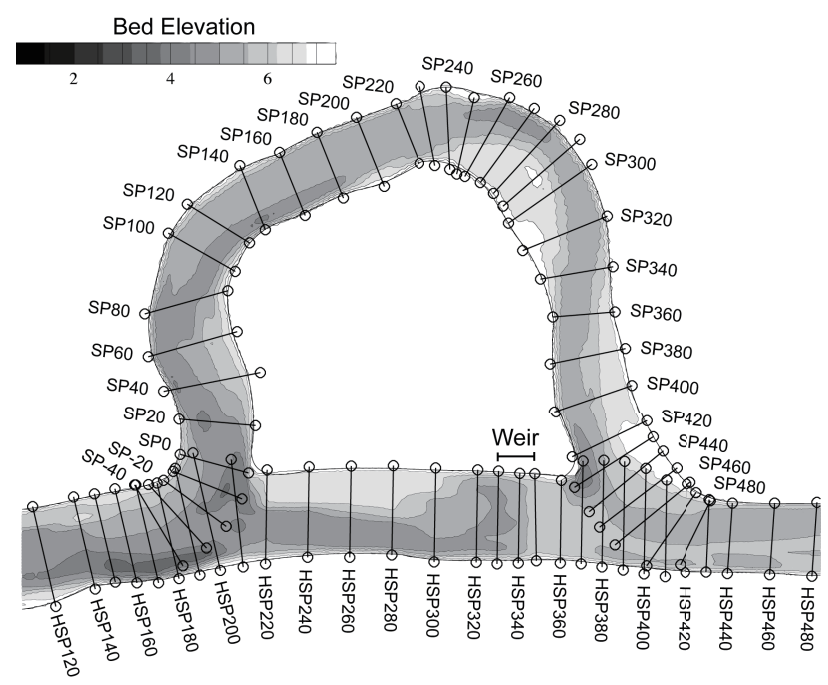

図-5 河道形状と河床高

きくなっていることがわかる．この傾向から合流部で の偏倚も計算によって再現されているといえる.

次に，本川，支川それぞれの縦断的な中心軸での水 位の実測值と計算結果を比較する。水位の観測位置は 図-3に破線で示した $\mathrm{y} 1, \mathrm{y} 2$ であり，それぞれの水位を 図-4に示す。本川下流部では計算值は実測值を良好に 再現しており，合流区間においても両者の值はほぼ一 致している，その一方，上流部では最大 $0.5 \mathrm{~cm}$ の差が みられた。支川においては上流部で最大 $0.5 \mathrm{~cm}$ の相違 がみられたものの合流部も含めた下流部では良好な再 現性を示した。これらの結果から四分木構造格子にお ける合流部の数值計算も概ね妥当であると判断できる.

\section{3. 標津川の再現計算}

実河川の分岐・合流部の四分木構造格子による計算 の適応性について調べるため北海道北東部の 2 級河川 である標津川を対象とし，再現計算を行った。また，洪 水時の降雨開始時から出水ピーク時までを計算するこ とで非定常時における計算の妥当性についても検証し た。計算結果の比較には実測值と著者ら ${ }^{9)}$ の過去に行 った一般座標系での解析結果を用いた。

\section{(1) 対象河川の概要}

標津川は図-5 に示すように河川環境を復元するため, 直線化された河道を旧蛇行河道に復元する試みがなさ れており, 直線部と蛇行部を有する 2 way 河道方式が採 用されている。分岐後の直線部では分流堰が設置され， 平常時には蛇行部への流水を促すように堰高が調整さ れている．わずか $300 \mathrm{~m}$ の区間に分岐と合流を有する 河道となっており，この区間の流況の把握には分岐・合 流それぞれの計算の妥当性および両者の一体的な解析 が求められる.

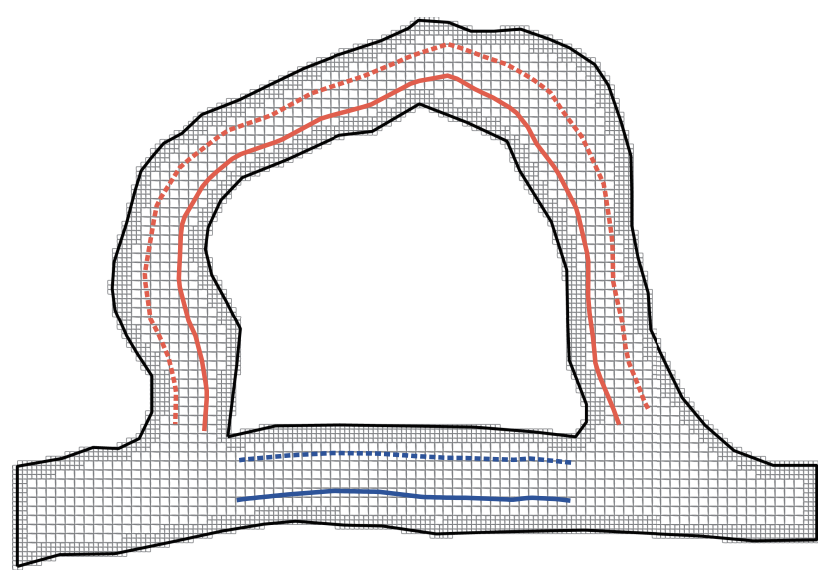

図-6 計算格子

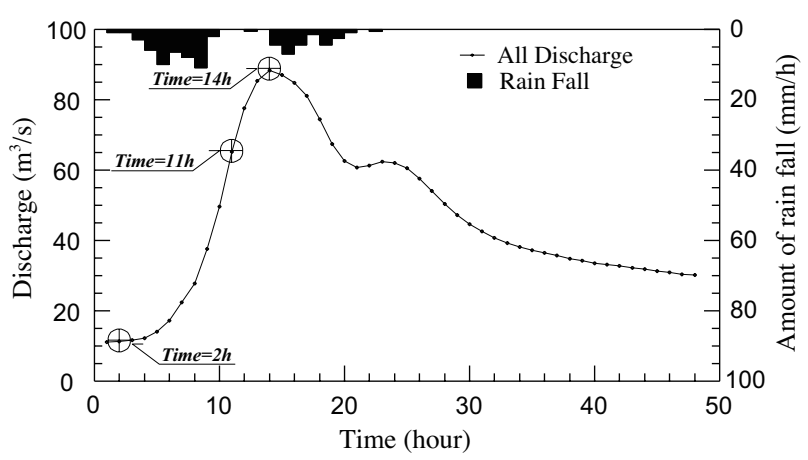

図-7 流量変化（2010/12/3 12:00～12/5 12:00）

\section{(2) 計算格子}

計算に用いた四分木構造の計算格子を図-6に示す。こ の計算格子は境界部に一辺 $2 \mathrm{~m}$ の計算格子を配置し，そ れ以外を一辺 $4 \mathrm{~m}$ の計算格子とし, 河道の平面形状を 表現した。この計算格子も実験水路と同様に著者らの 考案した格子生成法によって作成した。

著者らは一般座標系による解析も実施している。一 般座標の格子構成は自由度が高い反面, マトリクスの 連続性を維持する必要があるが, 手動でこの座標系が 要求する数学的な条件を満たした格子形状を得るため に多大な労力を要する。 そのうえ, 非定常計算を行う 場合では，一つの格子構成ですべての流量レンジを安 定に解析できる保証はない。その一方で, 四分木構造 格子では境界部の座標值さえ入力すれば格子生成の完 全なる自動生成 ${ }^{10)}$ が行える. しかも, 生成される格子 構成は必ず一意となる利点もある。このほか, 標高值 の設定によっては, 領域の中心部への冠水を一体的に 解析するための格子構成もできる.

\section{(3) 計算条件}

再現計算の対象としたのは年間最大流量を観測した 2010 年 12 月 3 日 23:00 前後で，このときの流量の時間 変化を図-7 に示す．図中に丸で示す $3 つ$ の時刻におい て実測值との比較を行った。 流量変化の大きい洪水時 
の計算を行ったことで非定常時の流れへの対応も検討 した.

\section{(4) 計算方法・境界条件}

計算方法については前章のものと同様に行つた。

Manning の粗度係数は著者ら ${ }^{12)}$ の計算条件と同様 に 0.041 とし, 計算の上流端の境界条件には流量フラッ クスを横断方向に一様に与え，下流端の境界条件には 実測值の水位を横断方向に一様に与えた。

\section{(5) 計算結果}

各時間ごとの計算結果を図-8，図-9，図-10 に示す。 各図の左上は四分木構造格子での計算結果の水深を示 しており，右側はその流線を表している。左下の図は 蛇行区間，直線区間それぞれの最大水深部での縦断的 な水位と河床高を示した。水位は赤線と青線で示して おり，それぞれ四分木構造格子および著者ら 9)の行っ た一般座標系での計算結果の值を示している．また図 中の四角形は水位の実測值を示している。右下の図は 図-6に示した線分上の流速を表しており，上から図-6 中の蛇行部右岸側（赤破線），蛇行部左岸側（赤実線）, 直線部右岸側 (青破線), 直線部左岸側（青実線）上の 四分木構造格子および一般座標系での流速の計算結果 を示している.

また全流量のうちの蛇行部に流れた流量の割合を求 めた流量配分比の計算結果と実測値を図-11 に示した。 なお，一般座標の計算では，いずれの流量でもわずか な水面変動を生じることが多かった。これに対して，四 分木構造格子は一貫した安定性を有することが確認さ れた。

\section{a) 降雨開始時:Time $=\mathbf{2 h}$}

図-8 の水深図を見ると直線部の堰上では水深が $0.5 \mathrm{~m}$ 以下となり，蛇行部が主流となっていることがわかる. 全体的には水深が $1 \mathrm{~m}$ に満たない箇所が大部分を占め, 蛇行部の外岸に沿う流れが明瞭に表れている。縦断水 位の実測值と比較すると，計算結果は両者とも高い再 現性を示しているが，一般座標系における計算では直 線部の堰下流部で水面に大きな起伏が確認できる．実 測值ではこのときの流量で直線部分に流れる流量は全 体の $10 \%$ 以下であることから堰下流部の直線区間での 水位変動は大きくないと考えられ，四分木構造格子で の計算のほうが実際の流れをより忠実に再現している と思われる。縦断的な流速はいずれも同様の傾向を示 した.

\section{b) 増水期:Time $=11 \mathrm{~h}$}

図-8の 9 時間後の図-9 では水深が $1 \mathrm{~m}$ を超える箇所 が多く存在し，合流部では水深が大きく，最大で $3 \mathrm{~m}$ の 水深を示す，堰上においても $1 \mathrm{~m}$ 程度の水深となる．実 測值と比べると蛇行部では四分木構造格子と一般座標 の両者の計算とも全体として高い再現性を示した。縦 断的な流速は一般座標系では変動が大きく，計算の不 安定さが読み取れる。一方，四分木構造格子では水深

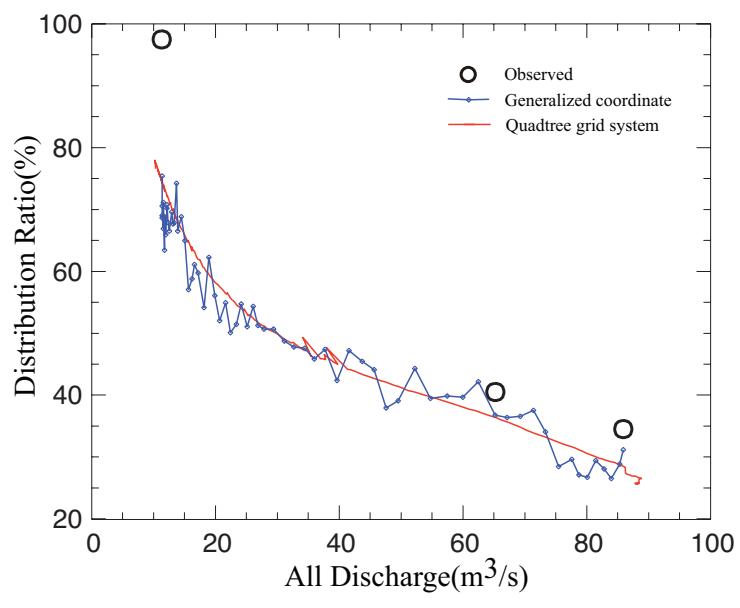

図-11 流量配分比

も流速も滑らかに連続しており，安定した計算が可能 であることがわかる。

\section{c) 出水ピーク時:Time $=14 \mathrm{~h}$}

出水のピーク時の図-10では図-9よりもさらに水深が 大きくなり，分岐部より下流では蛇行部，直線部の両 者ともに水深 $2 \mathrm{~m}$ 以上で流れる箇所が多くなる。流線 に着目すると直線部への流れが卓越しており, 流量の 増加とともに蛇行部から直線部へと流れが集中してい くことがわかる．実測水位を比較すると両者ともに蛇 行部では概ね一致し，直線部ではどちらの計算も全体 に水深が実測值と比べて小さく算出された。一般座標 系の縦断的な流速は四分木構造と比べると大きな変動 を示し，一般座標系での計算が安定していないことが 確認できる。

\section{d) 流量配分比}

図-11 は横軸に分岐前の流量，縦軸に全体の流量に対 する分岐後の蛇行部に流れる流量の比をとっている。一 般座標，四分木構造の計算結果は両者とも流量の増加 とともに流量の割合が蛇行部で小さく，直線部で大き くなるという特徵が再現された。しかしながら，どの 流量であっても計算值は直線部に過大に流れている傾 向となった。低流量時には特にその特徵が顕著に表れ る結果となった。

また，一般座標系の計算結果はここでも5\%程度の振 動を低流量時から洪水時まで常に示しており，計算結 果の不安定性が明らかである。一方で，四分木構造格 子ではいずれの流量時においてもその変化を滑らかに 追従が可能であることが示された。

\section{4. まとめ}

一般座標で格子構成が困難となる分岐・合流部では 四分木構造による格子生成が優位であり，なおかつ計 算の妥当性が認められた。

四分木構造格子はデカルト座標系を基準にしている 

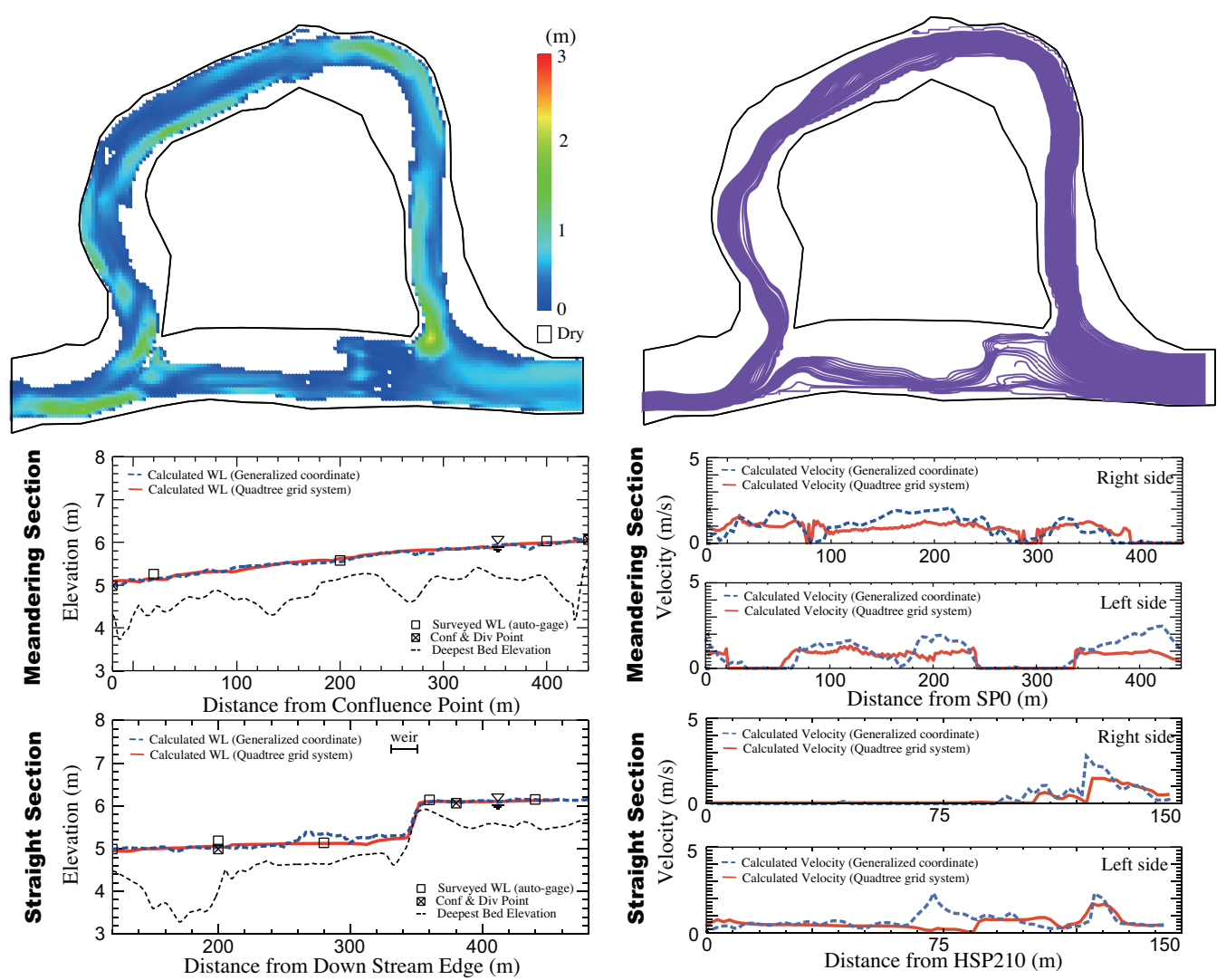

図-8 [Time $=2 \mathrm{~h}]$ 水深図 $($ 左上), 流線（右上）, 縦断水位 $($ 左下), 縦断流速 $($ 右下 $)$
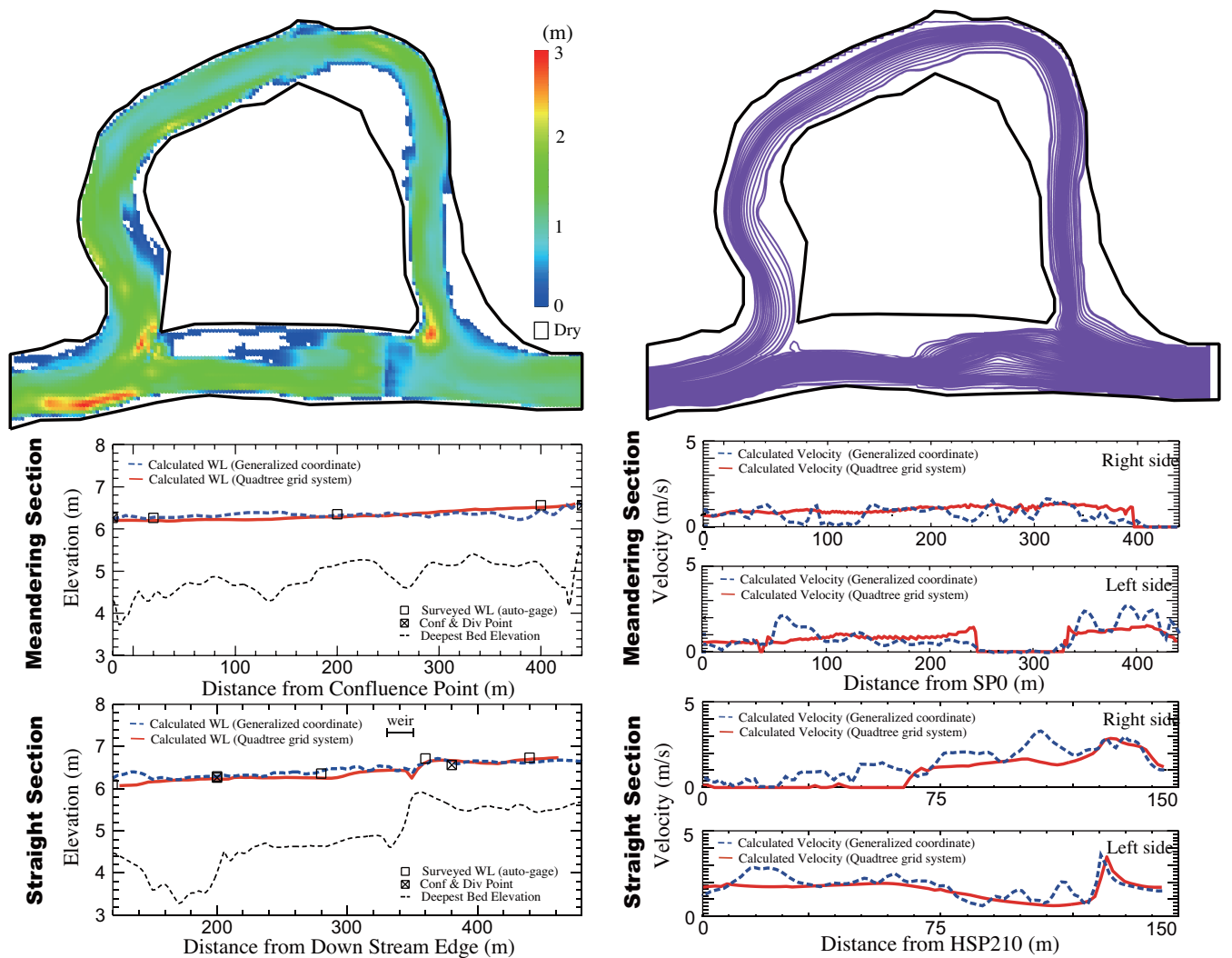

図-9 $[$ Time $=11 \mathrm{~h}]$ 水深図 (左上), 流線（右上）, 縦断水位 $($ 左下), 縦断流速（右下） 

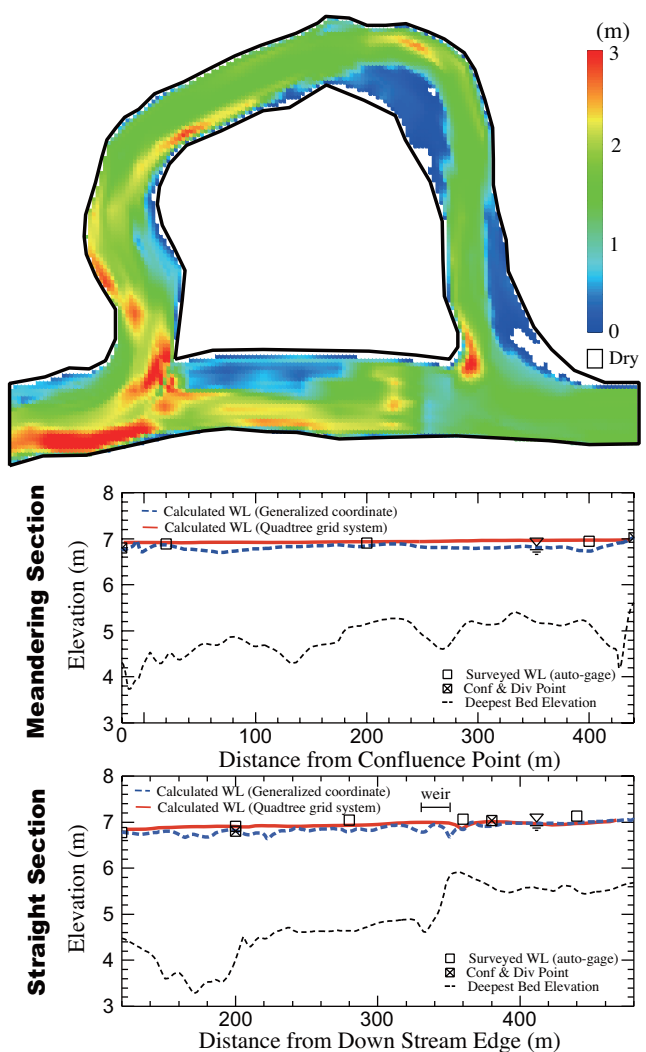

図-10 $[$ Time $=14 \mathrm{~h}]$ 水深図 $($ 左上 $)$, 流線（右上），縦断水位（左下），縦断流速（右下）
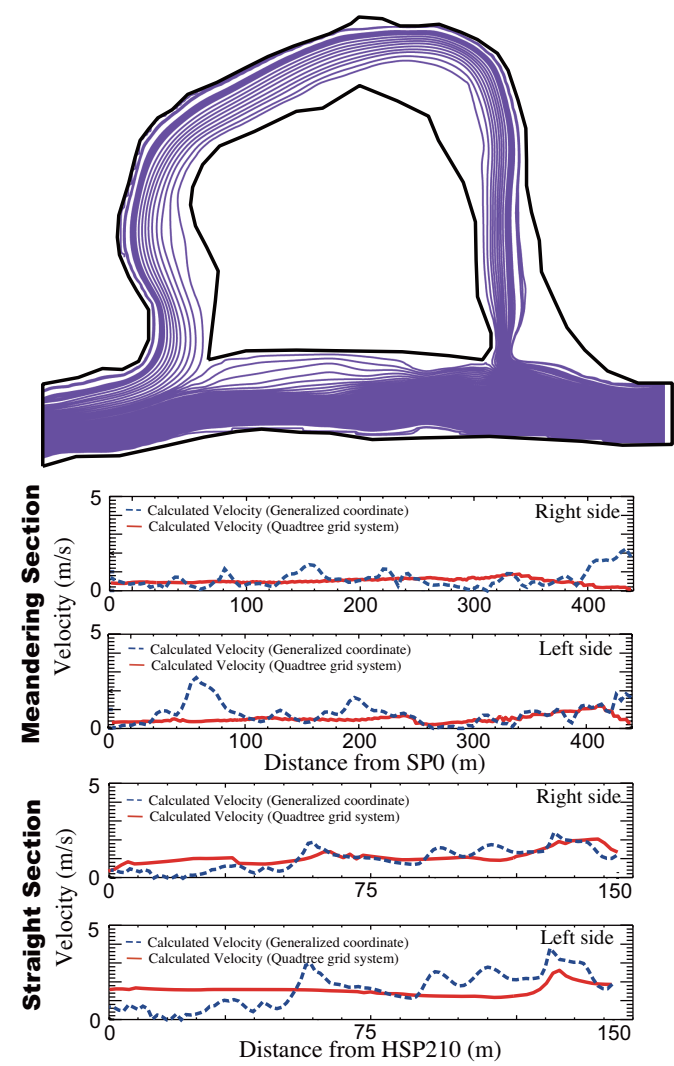

蛇行通水時の堰をともなう分岐流量配分比に関する研究, 土木学会水工学論文集, 第 47 巻, pp.529-534

5) 守屋薰, 長谷川和義, 小林賢也 : 常流移動床分岐水路にお ける河床不安定に関する研究，土木学会水工学論文集，第 51 巻

6) 北条紘次, 畑敏夫, 清水康行 : 合流部における 2 次元流況 計算法について，北海道開発局技術研究発表概要集，第 33 巻, pp.209-214, 1989

7) 内田龍彦, 福岡捷二: 浅水流方程式と渦度方程式を連立し た準三次元モデルの提案と開水路合流部への適用, 水工 学論文集, 第 53 巻

8) DINH,Thanh Mung, KIMURA,I. SHIMIZU,Y.:Computation of bed deformation at a river confluence using depth-averaged 2D models, RCEM2011

9) 永多朋紀, 安田浩保, 渡邊康玄 : 2 Way 河道の自律的な維 持を可能にする分流堰高に関する検討, 河川技術論文集, 第 17 巻, 2011

10）安田浩保, 星野剛 : 四分木構造格子による局所的な高解 像度格子を導入した浅水流方程式の数值解法, 土木学会 応用力学論文集

11）重枝未玲，秋山壽一郎，森山拓士 : 河川合流部周辺での 流れと河床変動の平面 2 次元解析, 土木学会水工学論文集, 第 53 巻, 2009

12) 岸力, 黒木幹男 : 移動床流れにおける河床形状と流体抵 抗 (1), 北大工学部研究報告 第 67 号, pp.1-23, 1973.

(2011.9.30 受付) 